\title{
New Accounting Guidance For Business Combinations
}

\author{
Allen W. McConnell, (E-mail: allen.mcconnell@unco.edu) University of Northern Colorado \\ Bill D. Cox, University of Northern Colorado \\ John E. Elsea, University of Northern Colorado
}

\section{A Brief History - Looking Back}

The Financial Accounting Standards Board (FASB) issued Statement of Financial Accounting Standards (SFAS) No. 141 Business Combinations in June 2001. SFAS 141 supersedes Accounting Principles Board (APB) Opinion No. 16 Business Combinations and SFAS No. 38 Accounting for Preacquisition Contingencies of Purchased Enterprises. APB Opinion 16 created two acceptable methods of accounting for a business combination, the purchase and the pooling of interests methods. These two different methods often resulted in very different financial results for economically similar transactions.

Since 1970, the primary guidance for accounting for business combinations has been APB Opinion 16. Even though the purchase and pooling of interests methods were not to be considered alternatives or substitutes, they have often been such in practice. For years, financial experts perceived that allowing the two accounting methods caused an uneven playing field for companies that were parties to business combinations. Problems with the uneven playing field were heightened when the continued growth of mergers and acquisitions crossed international boundaries.

APB Opinion 16 outlined twelve specific criteria that must be met for a business combination to be accounted for as a pooling of interests. When all twelve criteria were not met, the purchase method was required to be used. The controlling company could make sure the purchase method applied by structuring the combination so at least one of the criteria was not met. It was much more difficult to assure that the pooling method would apply since it was often difficult to meet all of the required criteria.

During the 1970s, the FASB had as an agenda item the reconsideration of accounting for business combinations. However, the Board postponed the business combinations project until it had completed the development of the conceptual framework for accounting and reporting. The FASB reinitiated the business combination project in 1996 due to increased merger and acquisition activity. In August 1999, the FASB broke the business combinations project into several projects that led to the issuance of SFAS 141 Business Combinations and SFAS 142 Goodwill and Other Intangible Assets.

\section{The Purchase Method}

With the issuance of SFAS 141, the purchase method became the only acceptable method of accounting for a business combination. The purchase method is now required for all business combinations initiated after June 30 , 2001 and for combinations initiated before June 30, 2001 when the terms of the agreement are altered after that date.

Application of the purchase method requires the:

- $\quad$ identification of the acquiring entity

- determination of the cost of the acquired entity

- determination of the costs of the business combination

$\overline{\text { Readers with comments }}$ or questions are encouraged to contact the authors via email. 
- $\quad$ identification of any contingent consideration

- $\quad$ allocation of the cost of an acquired entity to the assets acquired and liabilities assumed

- $\quad$ designation of an acquisition date and

- disclosure of significant information about the acquisition in the financial statements.

The purchase method requires the identification of an acquiring entity. When only one party is distributing assets or incurring liabilities, that entity is the acquiring entity. However, the identification of an acquiring entity is much more complicated when the combination is effected by the exchange of equity interests. In this case the following pertinent facts and circumstances need to be considered:

- $\quad$ which stockholder group retains or receives the largest voting interest

- when a large minority interest exists and no group has controlling interest, which group has the most significant voting interest

- $\quad$ composition of the governing body of the combined entity

- composition of the senior management of the combined entity and

- $\quad$ terms of exchange of equity securities.

\section{Cost Determination}

Determining the cost of assets acquired in a business combination follows the same accounting principles used to determine the cost of assets acquired individually or in a group. When the acquiring entity pays for the assets with cash no problems occur. However, the cost of the purchased assets becomes much more difficult to determine when payment is made in other assets, preferred stock, or common stock. For example,

- when assets are exchanged and liabilities incurred for assets acquired, the fair value of what is given up determines the cost of the assets acquired

- $\quad$ the issuance of preferred stock can cause a problem since preferred shares may have characteristics of either debt securities or common shares and

- $\quad$ the fair value of issued publicly traded common stock would normally provide the cost of the purchase in a business combination.

Direct costs of the business combination are added to the cost of the entity acquired. Costs related to registering and issuing equity securities should be deducted from the fair value of the securities. Indirect and general expenses related to the business combination should be expensed as incurred.

In many instances a business combination agreement may provide for additional consideration in the form of securities or cash. Normally the fair value of the contingency would increase the cost of the acquired entity. If the contingent consideration can be determined at the date of acquisition it should be added to the cost at that date. Normally the contingent consideration should be added to the cost when the contingency is resolved. However, when consideration is based on security prices it does not affect the cost of the acquired entity.

Allocating the cost of an acquired entity to the assets acquired and liabilities assumed should follow the purchase price allocation method, which allocates the cost to assets acquired and liabilities assumed based on their estimated fair values. Guidance for purchase price allocation is given in paragraph 37 of SFAS 141.

The excess of the cost of the acquired entity over the amounts assigned to the identifiable assets acquired and the liabilities assumed is recognized as goodwill. Goodwill is not amortized according to SFAS 142. Instead, goodwill should be reviewed for impairment at least once per year.

When the amounts assigned to assets acquired and liabilities assumed exceed the cost of the acquired entity, the excess is allocated as a pro rata reduction to the amounts that would have been assigned to all the assets acquired except: 
- $\quad$ financial assets other than investments accounted for under the equity method

- $\quad$ assets to be disposed of by sale

- $\quad$ deferred tax assets

- $\quad$ prepaid assets relating to pension or other postretirement benefit plans and

- $\quad$ any other current assets.

Any excess remaining, after the allocation described above, is reported as an extraordinary gain.

\section{Intangible Assets Other Than Goodwill}

Under APB Opinion 16, the price paid when one company acquired another company or its assets was first allocated to the tangible 'priority accounts' such as accounts receivable, inventory, investments and liabilities. Any additional value was next assigned to fixed assets. Then, intangible assets were identified, named and valued. In today's economy, intangible assets are becoming an increasingly larger proportion of the assets of many companies. An intangible asset, to be classified as an asset, must have attributes that can be measured reliably, and it must have probable future economic benefits according to Statement of Financial Accounting Concepts (SFAC) No. 5 Recognition and Measurement in Financial Statements of Business Enterprises and SFAC No. 6 Elements of Financial Statements, respectively. When considering the definition of an intangible asset for SFAS 141, the FASB took a broad view that intangible assets are assets that lack physical substance, but do not include financial assets.

In addition to the requirements set forth in SFAC 5 and SFAC 6, SFAS 141 adds two criteria: the contractual-legal criterion and the separabiltiy criterion. One of these must be met if the intangible asset is to be recognized separate from goodwill. An intangible asset that exists because of its contractual or legal rights is implied to have a future value that can be measured. Its value may or may not be separable from other assets of a company. For example, a patent has a value that is both legal and separable. On the other hand, it might be difficult to separate the trademark value of McDonald's golden arches from its production and marketing processes. A separable asset is one that can be separated or divided so that it can be sold, exchanged, licensed, rented or transferred (Fischer, Taylor $\&$ Cheng, 2002). The asset may or may not have a market currently and it may or may not be able to be sold separate from other assets, but it does have an identifiable value.

Intangible assets other than goodwill have either finite or indefinite lives. Those with finite lives are to be amortized over their estimated useful lives. Those considered to have indefinite lives are to be tested for impairment periodically.

To facilitate the determination of what might be included as an intangible asset other than goodwill, in paragraph A14 of SFAS 141 the Board provides examples of items that meet the specified criteria. These examples are grouped under the five categories that follow. Not all of the examples given by the Board are presented here.

- $\quad$ Marketing-related intangible assets. This group contains trademarks, trade dress, newspaper mastheads, internet domain names, and non-competition agreements. All of the items in this group are contractuallegal in nature.

- $\quad$ Customer related intangible assets. Customer lists, order or production backlogs, customer contracts, and non-contractual customer relationships are included here. Customer lists and non-contractual customer relationships are separable; the other two are contractual.

- $\quad$ Artistic-related intangible assets. The items in this group are primarily covered by copyright law and include plays, operas, books, magazines, musical works, pictures, motion pictures and many more.

- $\quad$ Contract-based intangible assets. As the heading states, the following are contract based: licensing agreements, royalty agreements, advertising and construction contracts, lease agreements, construction permits, franchise agreements, broadcast rights, water rights and mineral rights.

- $\quad$ Technology-based intangible assets. Patented technology, computer software, unpatented technology, databases and trade formulas are included here. Unpatented technology and databases are separable; the others are contractual. 
It should be noted that most of the items are contractual-legal in nature, and that some of them might also be separable. Since the vast majority of the listed items fall into the contractual-legal group, the practitioner may want to test for contractuality before considering separability.

The Board decided not to address two current and difficult areas in this pronouncement and excluded them from the recognition criteria. These are:

- $\quad$ accounting for research and development costs acquired in a business combination. The Board decided it could not address this issue without broadening its scope to include research and development costs in general. Thus, assets that are to be used in a specific research project that have no future alternative use will continue to be charged to expense at the time acquired.

- $\quad$ accounting for an assembled workforce and the related intellectual capital. The Board decided that there are not adequate methods available to determine the value of an assembled workforce or intellectual capital at this time. In the process they indicated that replacement cost would lack representational faithfulness.

After intangible assets other than goodwill have been properly valued, any remaining excess cost over book value is goodwill. Goodwill should be periodically tested for impairment as opposed to being amortized.

Required disclosures in notes to the financial statements of a combined entity are listed in paragraphs 51 through 58 of SFAS 141.

\section{Summary}

SFAS 141 Business Combinations provides guidance for all combinations initiated after June 30, 2001. The new guidelines require the use of the purchase method of accounting for combinations. This ended over thirty years of an either or situation with two methods, purchase or pooling of interests, providing different results when accounting for the same basic transaction. Under the new guidance, emphasis is placed on identification of the acquiring entity, determination of the cost of assets acquired, accounting for costs associated with the combination, and handling contingent consideration. Major changes have occurred in the area of intangible assets. Goodwill is considered to have an indefinite life and should not be amortized; however, it must be reviewed for impairment annually or more frequently. Intangible assets other than goodwill have either finite or indefinite lives. Those with finite lives are to be amortized over their estimated useful lives. Those considered to have indefinite lives are to be tested for impairment periodically.

\section{References}

1. American Institute of Certified Public Accountants. (1970). Opinions of the Accounting Principles Board Opinion No. 16: Business Combinations. New York: Author.

2. Fischer, Paul M., William J. Taylor and Rita H. Cheng. Advanced Accounting, $8^{\text {th }}$ ed. (2002). SouthWestern Publishing: Mason, OH.

3. Financial Accounting Standards Board. (1984). Statement of Financial Accounting Concepts No. 5: Recognition and Measurement in Financial Statements of Business Enterprises. Norwalk, CT: Author.

4. Financial Accounting Standards Board. (1985). Statement of Financial Accounting Concepts No. 6: Elements of Financial Statements. Norwalk, CT: Author.

5. $\quad$ Financial Accounting Standards Board. (1980). Statement of Financial Accounting Standards No. 38: Accounting for Preacquisition Contingencies of Purchased Enterprises. Norwalk, CT: Author.

6. Financial Accounting Standards Board. (2001). Statement of Financial Accounting Standards No. 141: Business Combinations. Norwalk, CT: Author.

7. Financial Accounting Standards Board. (2001). Statement of Financial Accounting Standards No. 142: Intangible Assets. Norwalk, CT: Author. 